\title{
THE IMPORTANCE OF ENVIRONMENTAL CERTIFICATES FOR GREEN HOTEL: BIBLIOMETRIC AND NETWORK ANALYSIS
}

\author{
Abdullah QUBBAJ $^{\text {a)}}$, Angel Peiro SIGNES ${ }^{\text {b) }}$ \\ Polytechnic University of Valencia (Universitat Politècnica de València), Valencia, SPAIN \\ a)e-mail: abqub@doctor.upv.es \\ b)e-mail: anpeisig@omp.upv.es
}

\begin{abstract}
Environmental problem has become a popular research area. Efforts are being made at an international level for creating a sustainable environment. Hospitality industry is considered to be one of the main industries of a country. It makes contributions in the development of sustainable environment. Hospitality industry is adopting environmental certifications and green hotels concept rapidly. In this research, we performed bibliometric analysis of 49 articles on the topic of importance of environmental certificates for green hotels. Results indicate that majority of the journals have articles with a large number of citations, which indicates that they are high-quality journals. The results indicate that Cornell University, Polytechnic University of Valencia, Hong Kong Polytechnic University, and George Washington University are the institutes producing high-quality research work, as $28 \%$ of the researchers cited the articles published by the researchers of these universities. Results indicate that universities of Spain and USA are the largest contributors, as they have published 52\% the total articles in the area under this study. USA and Spain are considered to be the world superpowers; their interest in this area of research unveils the importance of the topic. The authors Verma, Chan, and Rivera are the core researchers of this area, as they published $20 \%$ of the overall articles discussed in this study, which makes them the gurus of the research area.
\end{abstract}

Keywords: environmental certification, sustainability, tourism.

JEL Classification: M10, M30, Z30.

1

\section{Introduction}

Pollution is one of the biggest problems of the current era. It is considered a universal problem. Efforts are being made at an international level to overcome this problem. There are organizations that are working for creating a sustainable environment all over the world. Government and non-governmental organizations (NGOs) are making an effort to make this world pollution free. In this context, they are making efforts to create awareness among the general public and organizations to adopt the best practices which help in maintaining a sustaining environment. Hospitality industry is considered to be a core component of the economy of a country.

A great stress is given upon implementation of the best environment in the hospitality industry and increasing the number of green hotels worldwide. Since it is a popular agenda, it has been a research area widely studied since decades. Importance of environmental certifications has also received an immense popularity among researchers associated with environmental sciences and hospitality management. A lot of work has been done in the domain of environmental certifications and their impact on hospitality industry. An environmental certification is defined as a process that defines, monitors, and ensures that a business, process, product, or a system is aligned with specific standards (Pritchard, 1969).

In the perspective of hospitality industry (Pritchard, 1969), an environment certification has three main objectives, that is, it promotes the implementation of sustainable environment practices, it helps in enhancing the profitability of the hotel, and it helps in attracting potential guests using environmental performance of the hotel during the online hotel booking process. The study by Pritchard (1969) revealed that certifications provide the expertise in implementation of sustainable best environment practices and they help in reducing the "greenwash" claims too. Greenwash can be defined as a false impression that an organization, product, or service is environmentally sound. 
International Organization for Standardization (ISO) is an international NGO. It aims to develop worldwide standards for the exchange of products and services. ISO 14000 comprises 20 environmental standards. These standards are a combination of different guidelines focusing on environmental problems. Among these 20 standards, ISO 14001 is the only one which can make an organization certified. It contains five principles, that is, environmental policy, planning, implementation and operation, monitoring and corrective actions, and management review (Chan, 2011).

Research has shown that financial performance of hotels can be improved by adopting the best environmental practices (Blackman, et al., 2014), and customers also prefer hotels having ISO 14001 certifications. Due to the aforementioned facts, trend in hotels for the adoption of ISO certifications is increasing. Hotels are striving to adopt the best environmental practices, and for this purpose, they are spending a lot of money on the environmental certifications of their human resources. There are many organizations which are offering environmental certifications. ISO has introduced a number of certifications in the domain of environment sciences.

These certifications help in maintaining a sustaining environment in the society and ensure that the functioning of businesses is according to the guidelines of ISO. ISO 14001 environmental certifications have become very high in demand. These certifications have many benefits, but the most important benefits are twofold: these help in improving the internal operations and the other benefit is that they provide third-party sustainability credential, which helps in improving sales. According to Blackman, et al. (2014), ISO 14001 environmental certifications are associated with higher rates of hotels. In the Asia Pacific region, Hong Kong was the first country to have a hotel with ISO 14001 certification.

Apart from that, a large number of international hotels such as Serena, Marriot, Ramada, and Holiday Inn have adopted environmental certifications and are making their contribution in protecting the planet. But still, majority of the hotels are not ISO 14001 certified (Becken and McLennan, 2017), which indicates an alarming situation, and there is a need to spread word about the implementation of ISO 14001 certifications in the hospitality industry.

Literature on environmental certifications and their importance for green hotels has grown tremendously in the last few years. It is evident from the literature that green hotels perform higher than the non-green hotels. According to Blackman, et al. (2014), clients consider environmental certification as a key attribute of a green hotel. Hospitality industry has the potential to make significant contribution for the creation of sustaining environment. Hence, an increase in the number of green hotels will definitely make a contribution to the sustaining environment. This paper has been divided into five sections: 1 Introduction, 2 Literature Review, 3 Methodology, 4 Results and Discussion, and 5 Conclusion.

\section{Research objectives}

This research aims to perform bibliometric network analysis of the existing literature on the importance of environmental certificates for green hotels. The aim behind bibliometric network analysis is to fill the research gap. Some of the important research objectives are mentioned below:

a) to identify the number of publications in the area under consideration from 2010 to 2020;

b) to identify the institute with the highest number of publications;

c) to identify the author with the highest number of publications;

d) to identify the most popular journal in the area of interest; and

e) to identify the most productive country.

\section{Literature review}

Environmental certifications have immense importance in the hospitality industry, and it has been a popular research topic in the domain of hospitality industry. A large number of researchers have made significant contributions in this domain. Chan (2010) discussed the impact of environmental management systems (EMSs) on the work ethics of the hotel staff. Researchers used a qualitative case study, where they collected data from three types of employees, that is, executives, supervisors, and general staff members. 
They collected data through semi-structured interviews and performed a thematic analysis to answer the research questions. Results revealed that EMSs have both positive and negative impacts on the working attitude of hotel employees. A top-down approach for the implementation of EMS was found to be suitable for a hotel having large Chinese manpower. It was also observed that low employee involvement in the planning stage has no impact on employee commitment to an EMS.

Researchers like Tari (2010) analyzed the level of quality and environmental management concurrently. They analyzed the joint and individual impact of the level of quality and environmental management on the performance of hotels. They collected empirical data from 301 three- to five-star Spanish hotels and performed cluster analysis for the identification of the level of commitment with quality and the environment. They applied analysis of variance and regression analysis techniques on the data set and found that commitment to quality and environmental practices has a great impact on the performance of hotels.

The majority of the researchers focused on the implementation of EMS in large hotels, while very few researchers discussed the implementation of EMS in small- and medium-sized hotels (SMHs). In Chan (2012), the researchers addressed the research gap after the investigation and analysis of the application of EMSs in the context of hospitality. They conducted a qualitative study on the basis of data fetched from three levels of employees, that is, executives, supervisors, and general staff from an international hotel, and developed an in-depth understanding of the application of EMSs in the hospitality industry. They identified four core factors in the formation stage of the hotel's EMS, which are: 1) corporate governance, 2) leading activities, 3 ) initial gap analysis, and 4) collaboration with external consultancy. It was observed that EMSs can help in promoting a bottom-up approach to change.

A top-down methodology for the implementation of EMSs was more appropriate for a hotel with a large number of Chinese manpower due to cultural issues. In Chan (2011), the researchers pointed out the hurdles in the implementation and execution of formal EMS in SMHs in Hong Kong. Researchers conducted an investigative factor analysis and found that five significant factors, that is, deficiency of urgency, uncertainty of EMS standards, deficiency of qualified professionals, conflicting guidance, and unpredictable support, were hurdles in the adoption of EMS by SMHs.

Researchers discussed the actions taken by these hotels for the enhancement of their environmental performance. Value-added services also play an important role in the acquisition and retention of customer loyalty, which is considered to be one of the biggest challenges of the hospitality industry. Environmental certifications are also considered an important factor in customer retention. A large group of hotels are implementing environmental certifications for acquisition and retention of customer loyalty.

Researchers like Segarra-Ona (2012) analyzed the relationship between implementation of environmental certifications and revenue generation in the Spanish hospitality industry. They discussed the impact of moderating factors such as company size and the market segment on the business outcome. They used the empirical economic information of 2116 Spanish hotels (data gathered from SABI database) for the year 2008 (in this year, 108 properties got ISO 14001 certification). They used a qualitative analysis technique, which showed that there exists a significant difference in the revenue of ISO-certified hotels and the hotels that are not ISO certified. It was evident from the results that company size and organizational factors have a great influence on revenue.

In Blackman (2014), researchers used a novel hotel investment as a substitute to the private benefits, and fixed effects, and tendency score matching to resist the self-selection bias. The author observed that Blue Flag certification stimulates significant novel investment, particularly in luxury hotels and in economically edged clusters.

In Geerts (2014), researchers discussed three important objectives of environmental certification systems (EMSs) in the hospitality industry. They showed that environmental certifications promote the implementation of sustainability practices in the hospitality industry. Environmental certifications enhance profitability in the hotels and these certifications prove to be helpful in providing more accurate information to the guests. Researchers discussed the perception of managers about environmental certifications. 
They interviewed 21 managers of London-based hotels from a group of reputed hotels and analyzed the websites of 196 hotels and found that all these goals were not achieved. Apart from that, they discussed in detail how EMSs provide knowledge to hotel owners and help against the greenwash claims.

However, the impact of environmental certifications on productivity was not fully explained. Environmental certifications also help in decision-making. In Jesus (2011), researchers analyzed environmental certification-based decision-making in two axes, that is, motivation and judgment to recognize reasons for pro-environmental behavior of the management of the Spanish Eco-management and Audit Scheme (EMAS)-certified hotels. They employed mixed approaches for studying the perception of the EMAS and reasons for certifications with existing and lapsed EMAS-certified firms enumerated against expert interviews and documentary evidence. They identified four clusters in the hospitality industry: the first cluster was the strategic hotels, which was $22 \%$ of the total hospitality industry and was found to have high levels of cohesive environmental management; the second one was named as Followers, which was $48 \%$ of the total industry population and was the largest group; the third one was named Greenwashers, which was $11 \%$ of the total industry population and it was the smallest group; and the fourth cluster was named Laggers, which was $19 \%$ of the total industry population and was found to have low levels of integrated environmental management.

The majority of the hotels were found to be internally motivated in their aim and ad hoc in their policymaking, with partial understanding of externally driven benefits and motivation for more systematic management systems. This is a question mark on the success of EMAS as nonstop improvement management and as a market-based instruction instrument for hotels. A few of the hotels connected to high environmental standards to the opportunities of gaining market benefit, the majority desired to avoid legal challenges. EMS has a great impact on the hospitality industry.

Researchers (Peiro-Signes, 2014) examined the effect of hotels with ISO 14001 EMS from a customers' point of view. They analyzed the data of customer rating for 6850 Spanish hotels. The hotels they included in the study were a combination of hotels with ISO 14001 certifications and hotels without ISO 14001 certifications. It was revealed that customers rated high for the hotels with ISO certifications, while the hotels without ISO certifications were found to be low rated. Results were proved to be robust for hotel comfort and hotel services compared to other hotel characteristics.

Moreover, the most significant differences were noticed in expensive four-star hotels. Four-star hotels seem to achieve a distinct market advantage by environmental certifications. It was found that the management training provided by ISO 14001 can provide a competitive advantage for the hospitality industry. Apart from environmental certifications, green practices are also given due importance. Researchers (Kim, 2017) did a systematic analysis and identified research domains and formulated the definition of green practices in the context of hospitality. They reviewed 146 articles on green practices published from 2000 to 2014 in eight hospitality journals. Researchers used content to code articles using a standardized coding scheme. It was found that the number of articles on green practices is growing rapidly. Researchers identified three research domains for green practices in the hospitality literature, that is, organizational, operational, and strategic. They defined the green practice as a value-added business strategy that is beneficial for hospitality operations that engage in environmental protection initiatives.

A proposed framework can be helpful for practitioners in developing green practice strategies and for governments to develop effective green policies and reinforce activities aimed at environmental protection. It provides a theoretical foundation for future research related to green practices in the hospitality industry. Researchers created an organizational framework for a fragmented body of literature by identifying three research domains for green practices based on a systematic review of recently published articles in the hospitality industry.

Researchers (Martinez, 2018) developed a model to investigate the relationship between green practices, green image, environmental consciousness, and the behavioral intentions of customers in the context of a certified hotel. They examined the direct and moderating role of environmental consciousness in 
the formation of behavioral intentions based on green initiatives. They conducted a survey on the sample size of 502 hotel customers in Spain. Findings showed that customer perceptions of green practices have a direct positive effect on a hotel's green image.

At the same time, the green image has a direct positive effect on customer behavioral intentions toward certified hotels. It was also found that the higher the environmental consciousness of the consumers, the greater their intention to stay, to spread positive word of mouth, and pay a premium for environmentally certified hotels. Environmental proactivity impacts the performance of hotels. To discuss this impact, researchers (Pereira-Moliner, 2015) analyzed the influence of environmental proactivity on cost and differentiation competitive advantage and explored the double relationship between environmental proactivity and business performance. They selected a sample size of 350 three- to five-star Spanish hotels and classified them according to environmental proactivity and performance levels. They employed a two-step cluster analysis and examined significant differences between clusters. Results showed two types of environmental behaviors, that is, reactive and proactive.

Hotels with proactive environmental behavior developed significantly better cost and differentiation competitive advantage and achieved significantly higher performance levels. Hotels that achieved above-average business performance levels were significantly more environmentally proactive. Energy saving can be considered an important factor in the success of business.

In Chan (2012), researchers discussed that hotels could save cost and improve sustainability by implementing judicious energy-saving approaches without harming guest satisfaction. In Susskind (2014), researchers provided an important knowledge basis for harnessing water-energy nexus. They used a database of 876 environmentally certified hotels globally to explore the resource usage, achieved savings, and existence of different nexuses. Results indicated that the relationship among all the three resource indicators was significant, but particularly pronounced for the water-energy nexus, and indicated an intrinsically close relationship between "water for energy" and "energy for water."
In Becken (2017), the researchers have discussed in detail that the hotel managers adopt sustainable development practices in their establishment, given the presence of barriers to the adoption of such practices by hotel establishments and the lack of knowledge as to the ways and means by which a sustainable development orientation is developed and implemented. They used a qualitative approach to address the research questions. They discussed in detail why and how hotel managers proceed to develop and implement a sustainable development orientation, as well as the contextual factors that affect the extent to which sustainable development practices are adopted. Researchers (Prud'homme, 2016) explored three research questions related to the social and physical attributes of a firm's location with its engagement in a voluntary environmental program (VEP). They drew a sample of hotels participating in a Costa Rican VEP and found that a group of VEP-certified rivals' and firms' vicinity to a sanctified environment is positively correlated with a firm's level of VEP commitment. An interaction effect was revealed, such that the association between the number of VEP-certified rivals and the VEP engagement level is positively moderated by their firm proximity to a green location. This research aims to find insights into the articles published on the topic "The significance of environmental certifications in the hospitality industry" from 2010 to 2020 and discuss significant information about the articles.

\section{$3 \quad$ Methodology}

This research was conducted according to the bibliometric methodology. Scientific articles for the duration 2010-2020 using keywords "ISO 14001," "environmental certificates," and "green hotels" were searched on Web of Science database. Fig. 1 shows the illustration of our methodology.

Researchers used Web of Science for downloading the data set of articles. Initially, a large number of articles were downloaded. During the preprocessing step, duplicate and irrelevant articles were identified and removed. At the end of the preprocessing step, 49 articles were left, which were used for the analysis. 
First of all, researchers performed descriptive analysis on research articles to find out the insights of the articles.
In this section, important insights for the articles will be discussed.

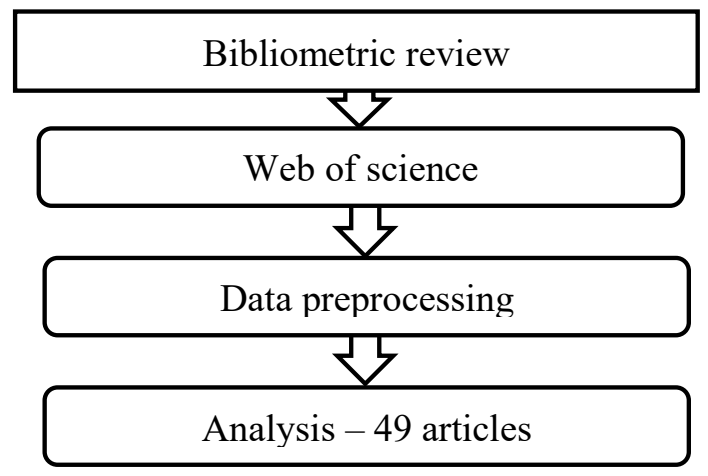

Figure 1. Illustration of methodology (Source: Created by authors)

\subsection{Bibliometric and social network analysis}

The word "Bibliometrics" was coined by Allan Pritchard in the year 1969 (Chan, et al., 2012). It is used to measure the knowledge growth with the help of research articles published by various researchers. It helps in finding significant contributions by researchers and countries in a particular research area. Apart from that, it helps in finding growth of knowledge in a specific time duration.

Social network analysis is used to identify and classify similar keywords' nodes, authors, and institutions to evaluate the associations and relationships between them (Chan, 2008).

This helps in identifying the relationship between certain components, that is, keyword frequency, also known as co-word; authors, also known as co-authorship; and citations, also known as co-citations.

This approach aims to identify the relationship between the different components of articles.

\subsection{Data collection}

We used Web of Science database to collect bibliometric data for the period from 2010 to 2020 . A total number of 49 articles for the last 11 years were collected and used in this research work.

\subsection{Analysis method}

For this research work, we used three main tools, that is, MS Excel, Histcite, and VosViewer software. MS Excel was used for data preprocessing, calculations, and graph creation. Histcite is a software used for bibliometric analysis and information visualization, while we used VosViewer for scientific mapping and clustering of the articles.

\section{$4 \quad$ Results and discussion}

\subsection{Publications' trend}

Publications' trend on the topic of "importance of environmental certificates for green hotel" for 49 research papers published from 2010 to 2020 has been shown in Fig. 2 and Table 1.

Articles published on the topic "Importance of environmental certificates for green hotels" from 2010 to 2020 have been shown in Fig. 2 and Table 1. It was found that the focus on the importance of environmental certificates for hotels is increasing year after year. Data shows that only a small percentage of work was published from 2010 to 2013. A drastic increasing trend in the number of publications was observed from the year 2014 onward, which shows that this topic got popularity among researchers after 2013, as most of the articles were published during this period. We can say that environmental problem increased with the modernization and got attention from researchers all over the world. 


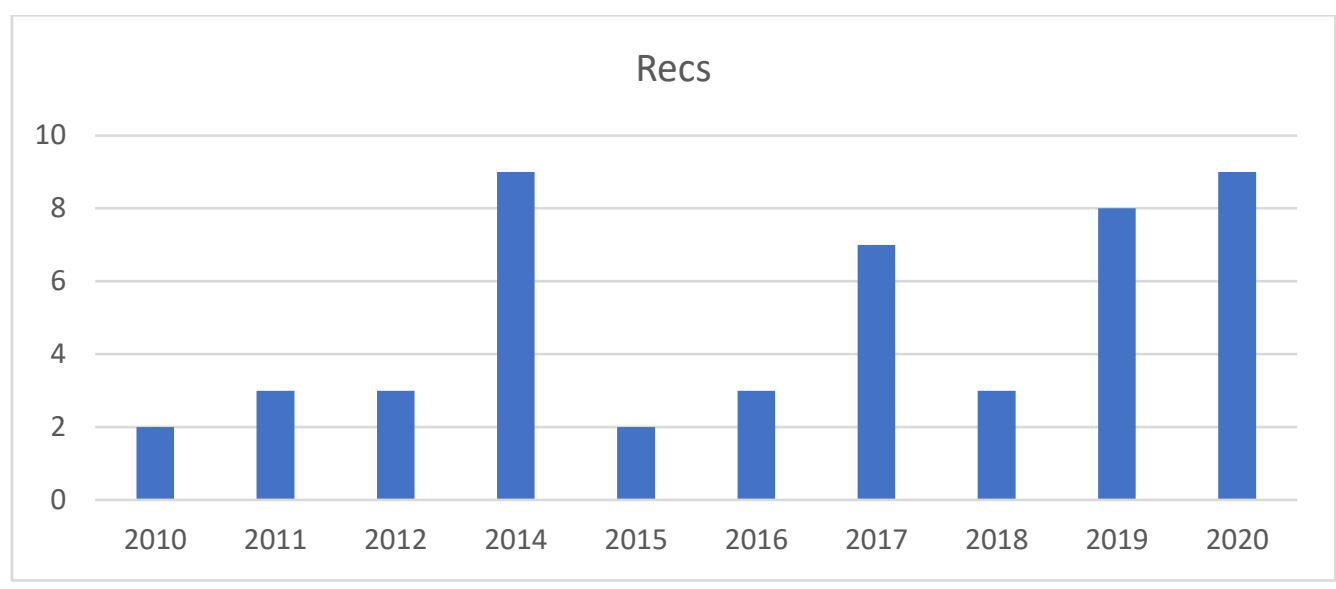

Figure 2. Publications' trend from 2010 to 2020

(Source: Created by the authors based on WoS database)

Table 1. Publications' trend from 2010 to 2020

(Source: Created by the authors based on WoS database)

\begin{tabular}{|c|c|}
\hline Publication year & Publications \\
\hline 2010 & 2 \\
\hline 2011 & 3 \\
\hline 2012 & 3 \\
\hline 2014 & 9 \\
\hline 2015 & 2 \\
\hline 2016 & 3 \\
\hline 2017 & 7 \\
\hline 2018 & 3 \\
\hline 2019 & 8 \\
\hline 2020 & 9 \\
\hline
\end{tabular}

\subsection{University citation score}

Researchers considered minimum two citations as a threshold for inclusion of universities in the list of universities with cited publications.

Fig. 3 and Table 2 show the universities with their publication citation score on the topic "Importance of environmental certificates for green hotels."

It is evident from Fig. 3 and Table 2 that the research work of Cornell University, George Washington University, Hong Kong Polytechnic University, and Universitat Politechnica De Valencia was cited 14 times in total by the researchers mentioned in the data, which indicates that these universities are striving to produce quality research in the area of environmental certifications in hospitality industry.

Other universities such as Boston, Alicante, Leeds Metropolitan, and Oxford Brookers University have a less focus on this topic, which indicates low research productivity by the universities and the need to improve the research quality. 


\section{Citations}

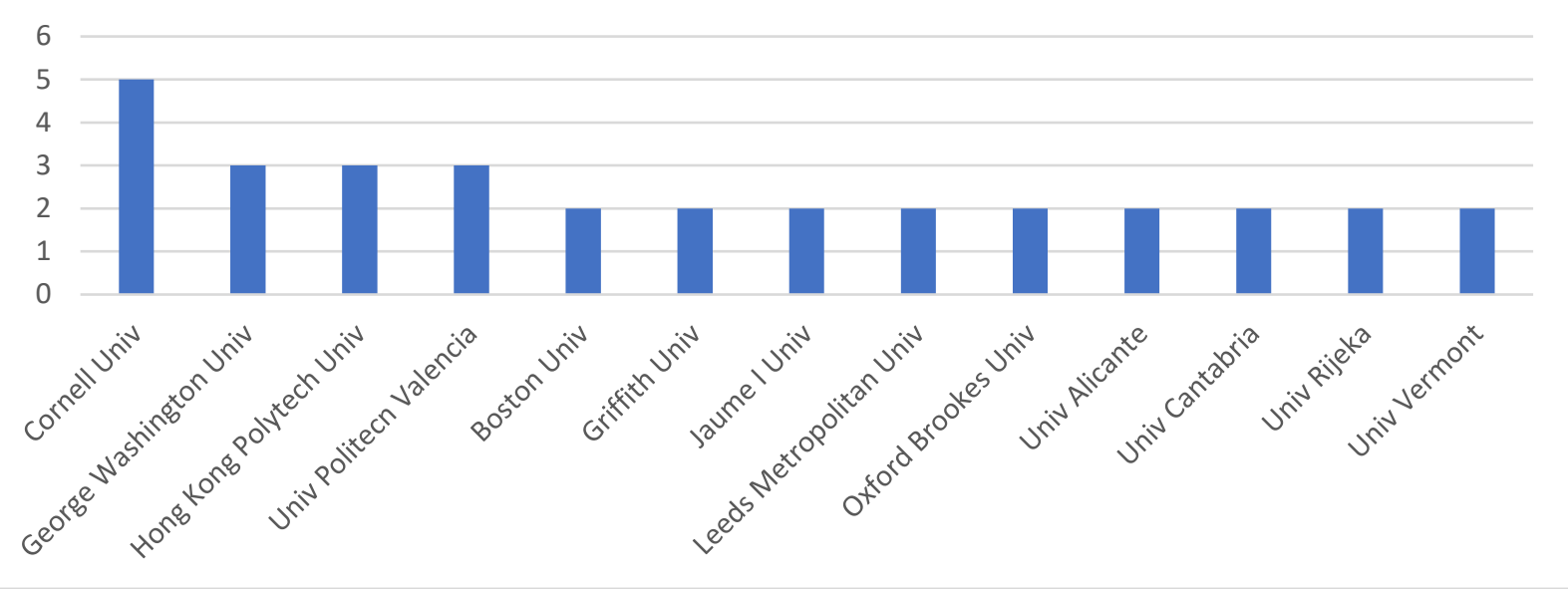

Figure 3. University citation scores (Source: Created by the authors based on WoS database)

Table 2. University citation scores (Source: Created by the authors based on WoS database)

\begin{tabular}{|c|l|c|}
\hline Rank & \multicolumn{1}{|c|}{ Institution } & Citations \\
\hline 1 & Cornell Univ & 5 \\
\hline 2 & George Washington Univ & 3 \\
\hline 3 & Hong Kong Polytech Univ & 3 \\
\hline 4 & Univ Politecn Valencia & 3 \\
\hline 5 & Boston Univ & 2 \\
\hline 6 & Griffith Univ & 2 \\
\hline 7 & Jaume I Univ & 2 \\
\hline 8 & Leeds Metropolitan Univ & 2 \\
\hline 9 & Oxford Brookes Univ & 2 \\
\hline 10 & Univ Alicante & 2 \\
\hline 11 & Univ Cantabria & 2 \\
\hline 12 & Univ Rijeka & 2 \\
\hline 13 & Univ Vermont & 2 \\
\hline
\end{tabular}

\subsection{Country-wise publications}

Researchers considered minimum five publications as a threshold for inclusion of universities in the list of universities with publications. Fig. 4 and Table 3 show the countries with publications on the topic "Importance of environmental certificates for green hotels."

It is evident from Fig. 4 and Table 3 that most of the publications on the topic "Importance of environmen- tal certificates for green hotels" were by the universities of Spain and USA, which indicates that these countries are making significant research contributions in the area and are high-ranked universities in producing quality research.

Data shows that only a small percentage of the articles were published by the universities of Turkey, Chile, and Costa Rica, which indicates low research productivity by these countries and the need to pay attention toward improvement of research quality. 


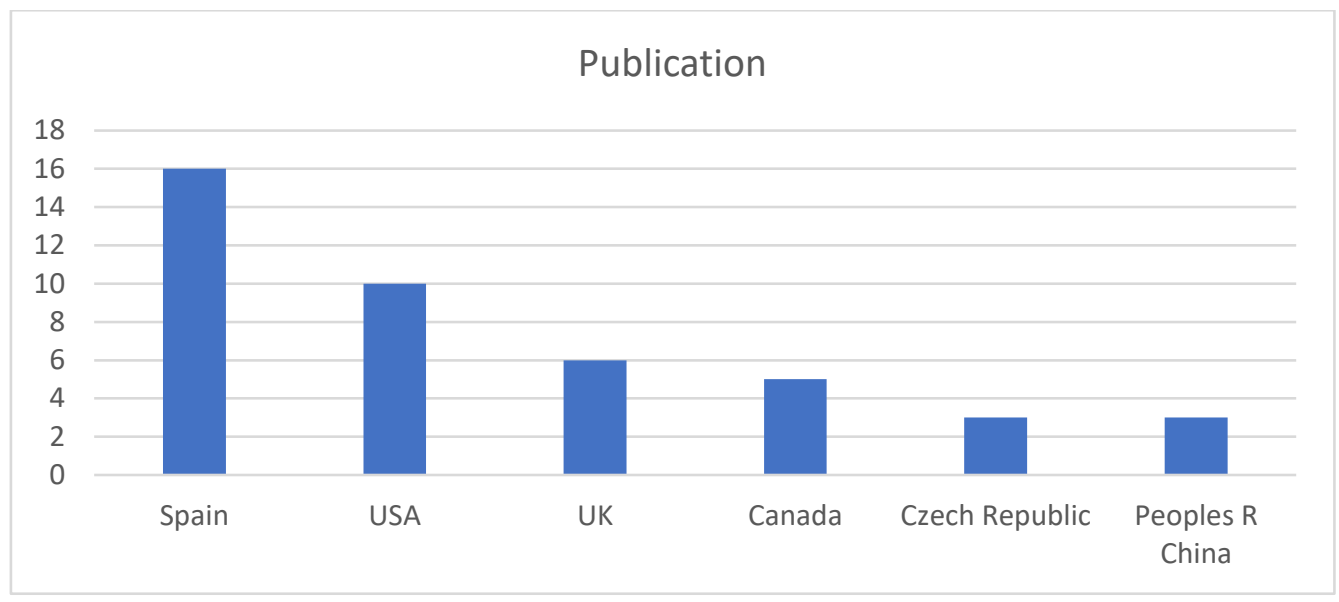

Figure 4. Country-wise publications (Source: Created by the authors based on WoS database)

Table 3. Country-wise publications (Source: Created by the authors based on WoS database)

\begin{tabular}{|l|c|}
\hline \multicolumn{1}{|c|}{ Country } & Publications \\
\hline Spain & 16 \\
\hline USA & 10 \\
\hline UK & 6 \\
\hline Canada & 5 \\
\hline The Czech Republic & 3 \\
\hline Peoples R China & 3 \\
\hline
\end{tabular}

\subsection{Top author}

Researchers considered minimum two publications as a threshold for inclusion of authors in the list of authors with publications. Fig. 5 and Table 4 show the universities with their publication citation score on the topic "Importance of environmental certificates for green hotels."
It is evident from Fig. 5 and Table 4 that $20 \%$ of the articles were published by the authors Verma R., Chan E.S.W, and Rivera J., which makes them the top researchers of the area. The authors Allur E., PeiroSignes A., Boiral O. and Zhang J.J have also contributed two publications each.

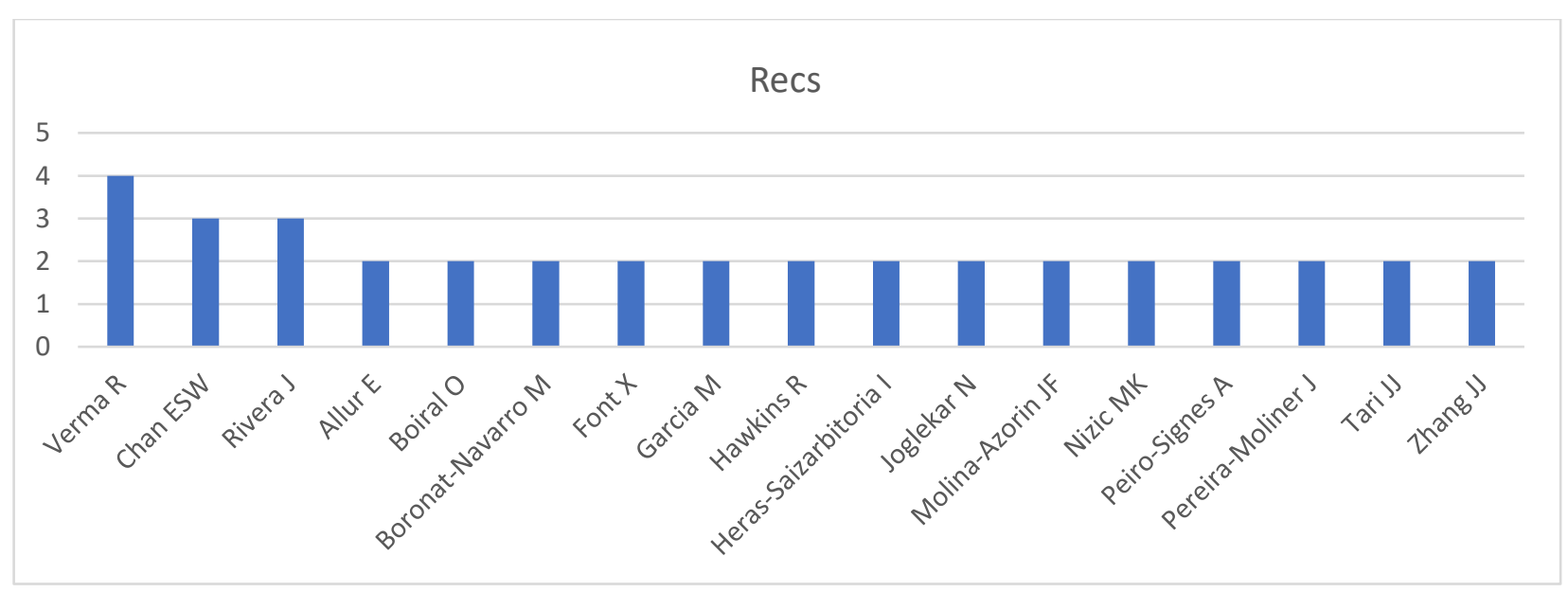

Figure 5. Publications by authors (Source: Created by the authors based on WoS database) 
Table 4. Publications by authors (Source: Created by the authors based on WoS database)

\begin{tabular}{|l|l|l|c|}
\hline \multicolumn{1}{|c|}{ Author } & Publications & \multicolumn{1}{c|}{ Author } & Publications \\
\hline Verma R & 4 & Hawkins R & 2 \\
\hline Chan ESW & 3 & Heras-Saizarbitoria I & 2 \\
\hline Rivera J & 3 & Joglekar N & 2 \\
\hline Allur E & 2 & Molina-Azorin JF & 2 \\
\hline Boiral O & 2 & Nizic MK & 2 \\
\hline Boronat-Navarro M & 2 & Peiro-Signes A & 2 \\
\hline Font X & 2 & Pereira-Moliner J & 2 \\
\hline Garcia M & 2 & Tari JJ & 2 \\
\hline Hawkins R & 2 & Zhang JJ & 2 \\
\hline
\end{tabular}

\subsection{Keyword frequency}

Researchers considered minimum eight frequencies as a threshold for inclusion of a keyword in the list of keywords with higher frequency.
Fig. 6 and Table 5 show the keywords with their frequencies on the topic "Importance of environmental certificates for green hotels."

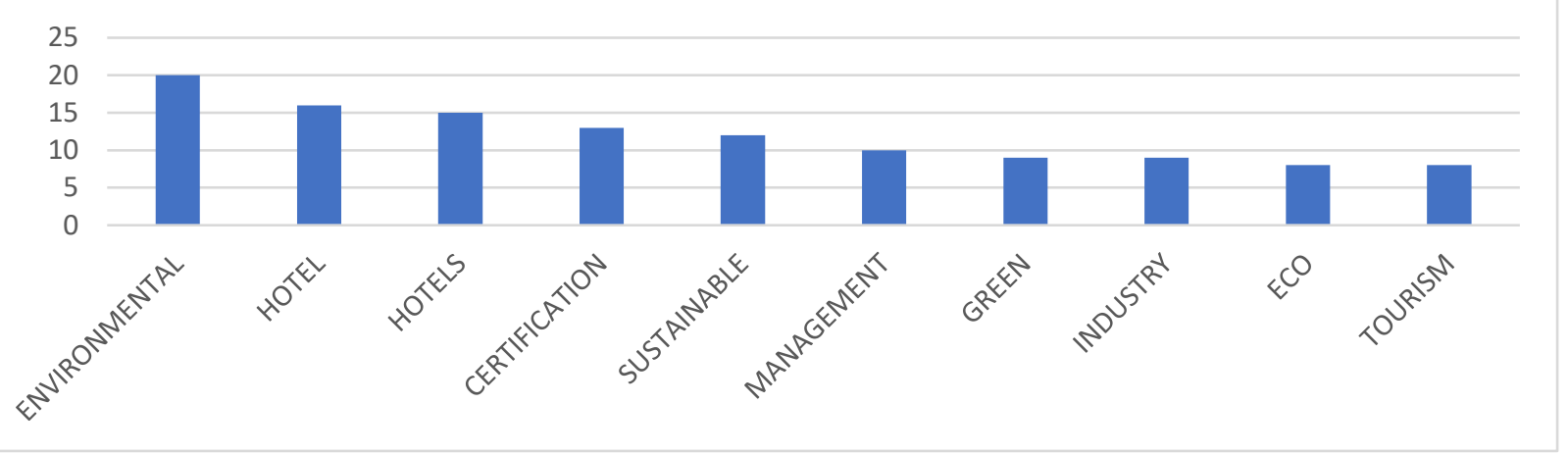

Figure 6. Keyword frequency (Source: Created by the authors based on WoS database)

Table 5. Keyword frequency (Source: Created by the authors based on WoS database)

\begin{tabular}{|c|l|c|}
\hline & \multicolumn{1}{|c|}{ Keyword } & Frequency \\
\hline 1 & Environmental & 20 \\
\hline 2 & Hotel & 16 \\
\hline 3 & Hotels & 15 \\
\hline 4 & Certification & 13 \\
\hline 5 & Sustainable & 12 \\
\hline 6 & Management & 10 \\
\hline 7 & Green & 9 \\
\hline 8 & Industry & 9 \\
\hline 9 & Eco & 8 \\
\hline 10 & Tourism & 8 \\
\hline
\end{tabular}


It is evident from Fig. 6 and Table 5 that the keywords "Environmental," "Hotel," and "Certification" appeared the most among all the keywords mentioned above, which makes them the most important keywords in the articles.

Other keywords such as "Sustainable," "Green," "ECO," and "Tourism" appeared less in the articles, which shows that these are the less important keywords and are less important in articles on the topic
"Importance of environmental certificates for green hotels."

\subsection{Journal popularity}

Researchers considered minimum two research papers as a threshold for inclusion of a journal in the list of journals with higher popularity. Fig. 7 and Table 6 show the journals with research papers on the topic "Importance of environmental certificates for green hotels."

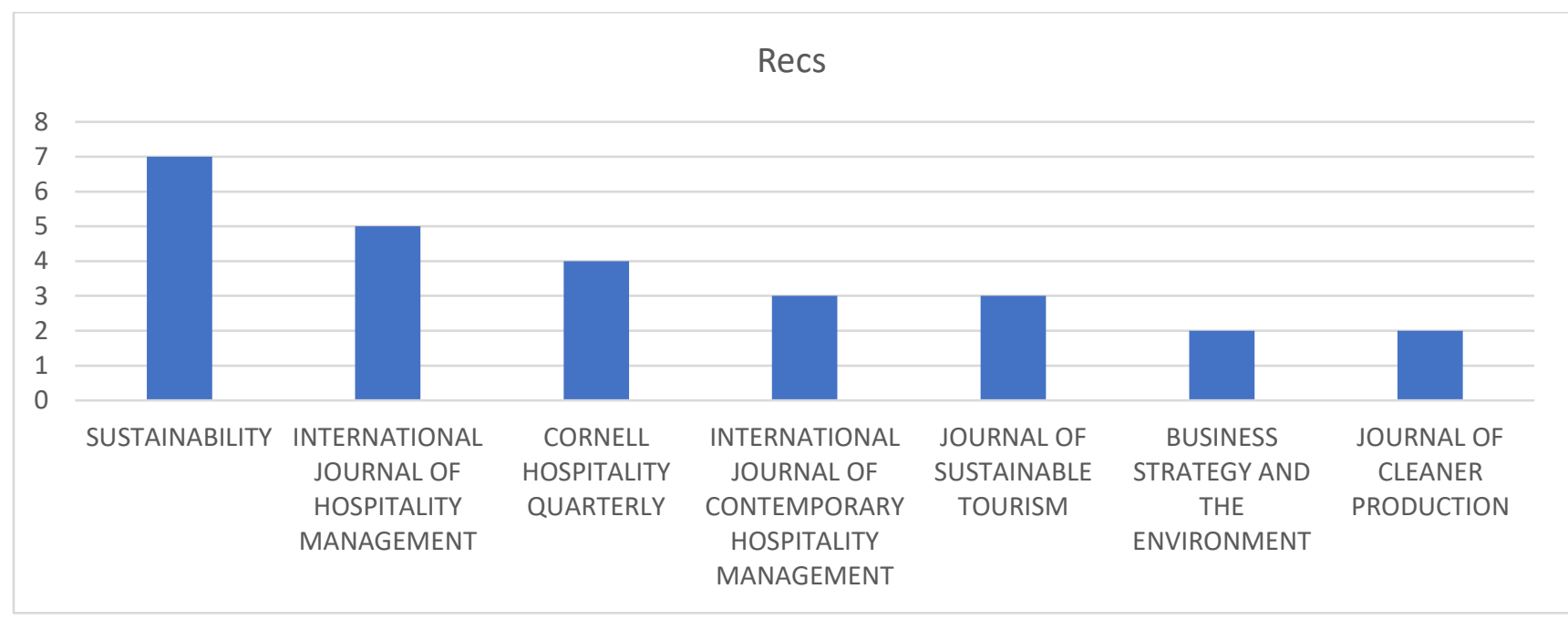

Figure 7. Journal popularity (Source: Created by the authors based on WoS database)

Table 6. Journal popularity (Source: Created by the authors based on WoS database)

\begin{tabular}{|c|l|c|c|}
\hline Ranking & \multicolumn{1}{|c|}{ Journal } & Number of articles & Q \\
\hline 1 & Sustainability & 7 & Q2 \\
\hline 2 & International Journal of Hospitality Management & 5 & Q1 \\
\hline 3 & Cornell Hospitality Quarterly & 4 & Q1 \\
\hline 4 & International Journal of Contemporary Hospitality Management & 3 & Q1 \\
\hline 5 & Journal of Sustainable Tourism & 3 & Q1 \\
\hline 6 & Business Strategy and the Environment & 2 & Q1 \\
\hline 7 & Journal of Cleaner Production & 2 & Q1 \\
\hline
\end{tabular}

It is evident from Fig. 7 and Table 6 that $32 \%$ of the articles belonged to the journals "Sustainability," "International Journal of Hospitality Management," and "Cornell Hospitality Quarterly," which makes them the most popular journals in the area of hospitality management.
The rest of the articles belonged to other journals such as "International Journal of Contemporary Hospitality Management," "Business Strategy and the Environment," and "Journal of Cleaner Production," which indicates that these journals are not much popular and they need to be focused. 


\subsection{Identifying core literature}

Table 7 shows the ranking of articles from the year 2010 to 2020. It was found that article "Levels of quality and environmental management in the hotel industry: Their joint influence on firm performance" by Tari, et al. (2010), published in the journal International Journal of Hospitality Management was the most cited article with 102 citations, which is the highest citation count.

The article "Attitude towards EMSs in an international hotel: An exploratory case study" by Chan, et al. (2010) published in the journal International
Journal of Hospitality Management was cited 101 times, which is the second highest citation count.

The article "Implementing environmental management systems in small- and medium-sized hotels: Obstacles" by Chan, Eric (2011) published in Journal of Hospitality \& Tourism Research was cited 97 times, which is the third highest citation count.

While the article "Does environmental certification help the economic performance of hotels?: Evidence from the Spanish hotel industry" by Segarra-Ona, et al. (2012), published in the journal Cornell Hospitality Quarterly was cited 67 times.

Table 7. Citation of articles (Source: Created by the authors based on WoS database)

\begin{tabular}{|c|c|c|c|c|}
\hline Authors & Title & Year & Journal & Citation \\
\hline $\begin{array}{l}\text { Tari, J.J., } \\
\text { Claver-Cortes, E.and } \\
\text { Pereira-Moliner, J. }\end{array}$ & $\begin{array}{l}\text { Levels of Quality and Envi- } \\
\text { ronmental Management in } \\
\text { the Hotel Industry: Their } \\
\text { Joint Influence on Firm Per- } \\
\text { formance }\end{array}$ & 2010 & $\begin{array}{c}\text { International Journal } \\
\text { of Hospitality Management }\end{array}$ & 102 \\
\hline $\begin{array}{l}\text { Chan, E.S.W., } \\
\text { Hawkins, R. }\end{array}$ & $\begin{array}{l}\text { Attitude Towards EMSs } \\
\text { in an International Hotel: } \\
\text { An Exploratory Case Study }\end{array}$ & 2010 & $\begin{array}{c}\text { International Journal } \\
\text { of Hospitality Management }\end{array}$ & 101 \\
\hline Chan, E.S.W. & $\begin{array}{l}\text { Implementing Environmental } \\
\text { Management Systems } \\
\text { in Small- and Medium-sized } \\
\text { Hotels: Obstacles }\end{array}$ & 2011 & $\begin{array}{l}\text { Journal of Hospitality \& } \\
\text { Tourism Research }\end{array}$ & 97 \\
\hline $\begin{array}{l}\text { Segarra-Ona, } \\
\text { Maria-del-Val, } \\
\text { Peiro-Signes, A. and } \\
\text { Verma, R. }\end{array}$ & $\begin{array}{l}\text { Does Environmental Certifi- } \\
\text { cation Help the Economic } \\
\text { Performance of Hotels?: } \\
\text { Evidence from the Spanish } \\
\text { Hotel Industry }\end{array}$ & 2012 & Cornell Hospitality Quarterly & 67 \\
\hline Geerts, W. & $\begin{array}{l}\text { Environmental Certification } \\
\text { Schemes: Hotel Managers' } \\
\text { Views and Perceptions }\end{array}$ & 2014 & $\begin{array}{c}\text { International Journal } \\
\text { of Hospitality Management }\end{array}$ & 60 \\
\hline $\begin{array}{l}\text { Priego, M.J.B., } \\
\text { Najerab, J.J. and Font, X. }\end{array}$ & $\begin{array}{l}\text { Environmental Management } \\
\text { Decision-making in Certified } \\
\text { Hotels }\end{array}$ & 2011 & $\begin{array}{c}\text { Journal of Sustainable } \\
\text { Tourism }\end{array}$ & 60 \\
\hline $\begin{array}{l}\text { Peiró-Signes, A., Segarra- } \\
\text { Oña, M., Verma, R., } \\
\text { Mondéjar-Jiménez, J. and } \\
\text { Vargas-Vargas, M. }\end{array}$ & $\begin{array}{l}\text { The Impact of Environmen- } \\
\text { tal Certification on Hotel } \\
\text { Guest Ratings }\end{array}$ & 2014 & Cornell Hospitality Quarterly & 49 \\
\hline $\begin{array}{l}\text { Kim, S.-H., Lee, K. and } \\
\text { Fairhurst, A. }\end{array}$ & $\begin{array}{l}\text { The Review of "green" Re- } \\
\text { search in Hospitality, 2000- } \\
2014 \text { Current Trends and Fu- } \\
\text { ture Research Directions }\end{array}$ & 2017 & $\begin{array}{c}\text { International Journal } \\
\text { of Hospitality Management }\end{array}$ & 42 \\
\hline
\end{tabular}




\subsection{Bibliographic coupling}

In order to have a clear picture of the academic background of 49 articles used in this research, researchers analyzed the articles' network. Fig. 8 illustrates the network visualization of bibliographic coupling of articles.

Fig. 8 presents the articles with the highest link strength of bibliographic coupling. Fig. 8 shows that the three studies with the highest indices of bibliographic coupling are:

- Manganari E.E., Dimara, E., Theotokis, A., 2016. Greening the lodging industry: Current status, trends and perspectives for green value. Current Issues in Tourism, Vol. 19, No. 3, pp.223-242.

- Kim, S.-H., Lee, K. and Fairhurst, A., 2017, The review of "green" research in hospitality, 2000
2014: Current trends and future research directions. International Journal of Contemporary Hospitality Management, Vol. 29, No. 1, pp.226-247.

- Pereira-Moliner, J., Font, X., Tarí, J.J., Molina-Azorín, J.F., Lopez-Gamero, M.D., 2015. The Holy Grail Environmental management, competitive advantage and business performance in the Spanish hotel industry. International Journal of Contemporary Hospitality Management, Vol. 27, No. 5, pp.714-738.

- Segarra-Ona, Maria-del-Val, Peiro-Signes, A., Verma, R., 2012. Does environmental certification help the economic performance of hotels?: Evidence from the Spanish hotel industry. Cornell Hospitality Quarterly, Vol. 53, No. 3, pp.242-256.

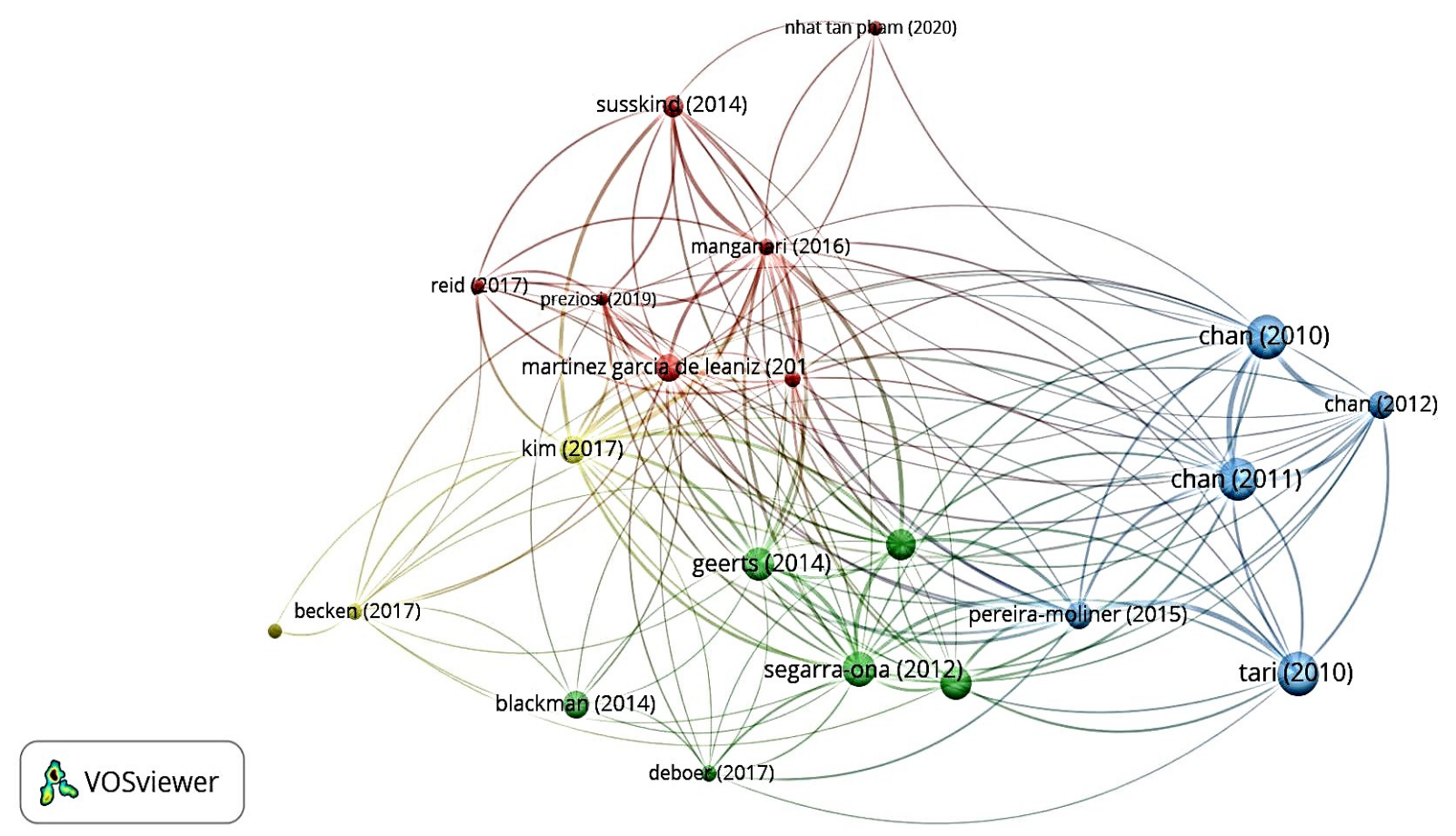

Figure 8. Network diagram for bibliographic coupling

(Source: Created by the authors based on WoS database using VosViewer software)

Trying to complete the Bibliographic coupling analysis of articles, Fig. 8 presents a network visualisation. The figure reveals four main clusters of documents that are commonly cited together. Manganari E.E., Dimara, E., Theotokis, A. (2016) has the biggest link strength and belongs to the red cluster with other articles, such as Susskind (2014), Reid (2017).
On the other hand, Kim, et al. (2017) is close to the leader in terms of bibliographic coupling and belongs to the yellow cluster, like Becken (2017). Pereira-Moliner (2015) leads the blue cluster, where we can find documents with a relevant link strength such as Chan (2010). Finally, Segarra-Ona (2012) leads the green cluster, where we can find documents with a relevant link strength such as Peiro-Signes (2014). 


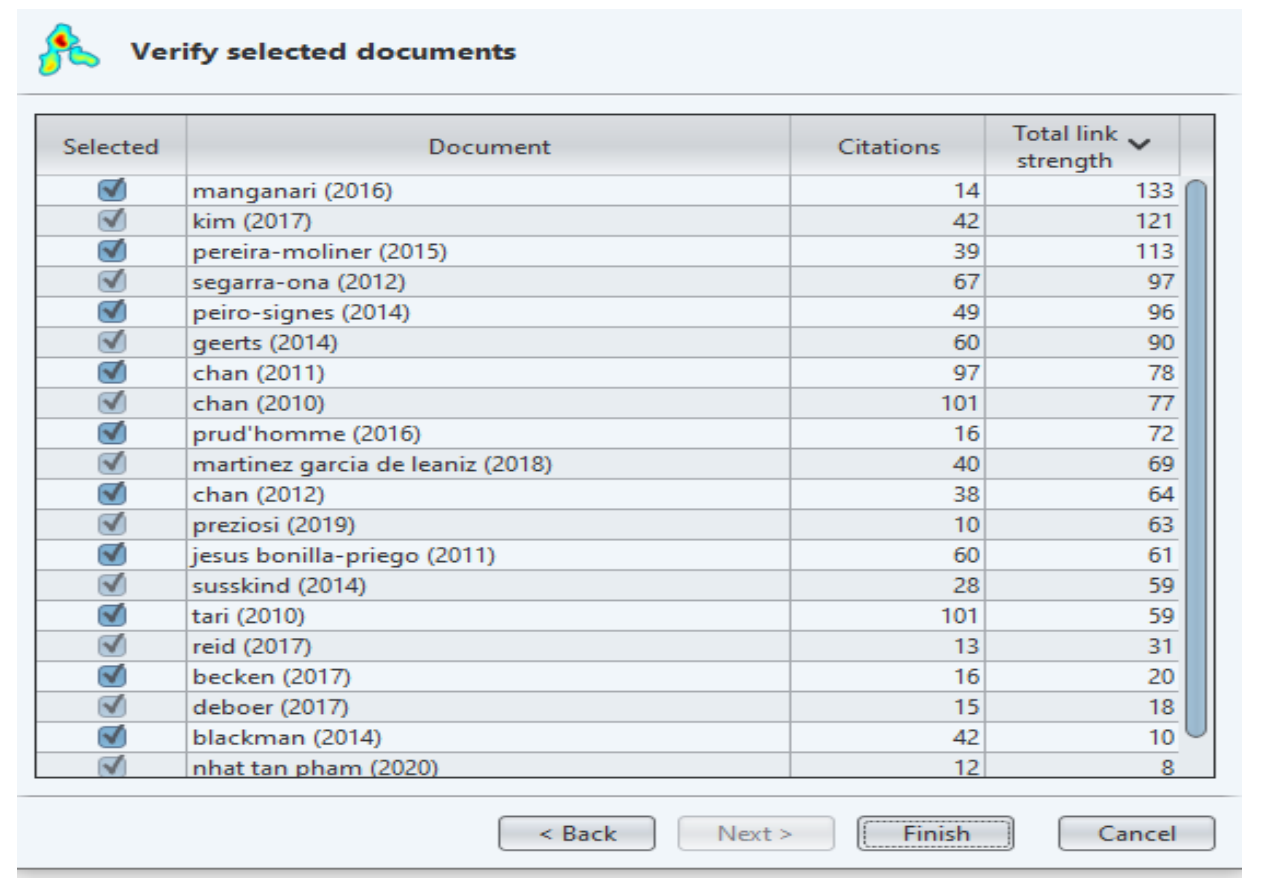

Figure 9. Bibliographic coupling

(Source: Created by the authors based on WoS database using VosViewer software)

\subsection{Co-citations}

Figs 10 and 11 identifies two main groups of cited documents in the literature. The green cluster is formed by four very relevant works cited frequently together in our sample (Lee, Font, Manaktola, and Greets). The red group is made up of seven articles, usually cited jointly (Priego, Chan, Tzschentke, Bohdanowicz, and Segarra-Ona).

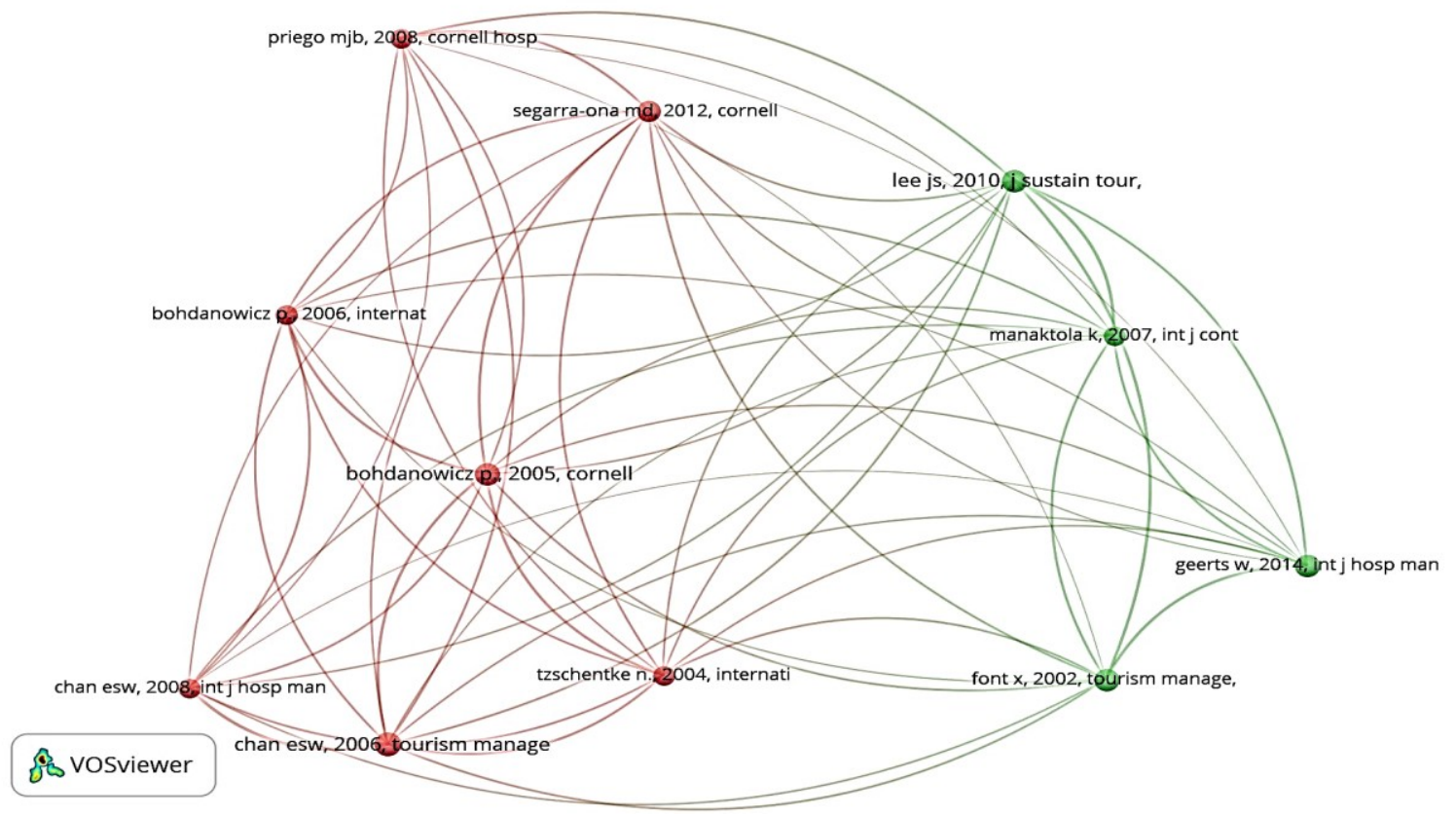

Figure 10. Network diagram of co-citations

(Source: Created by the authors based on WoS database using VosViewer software) 


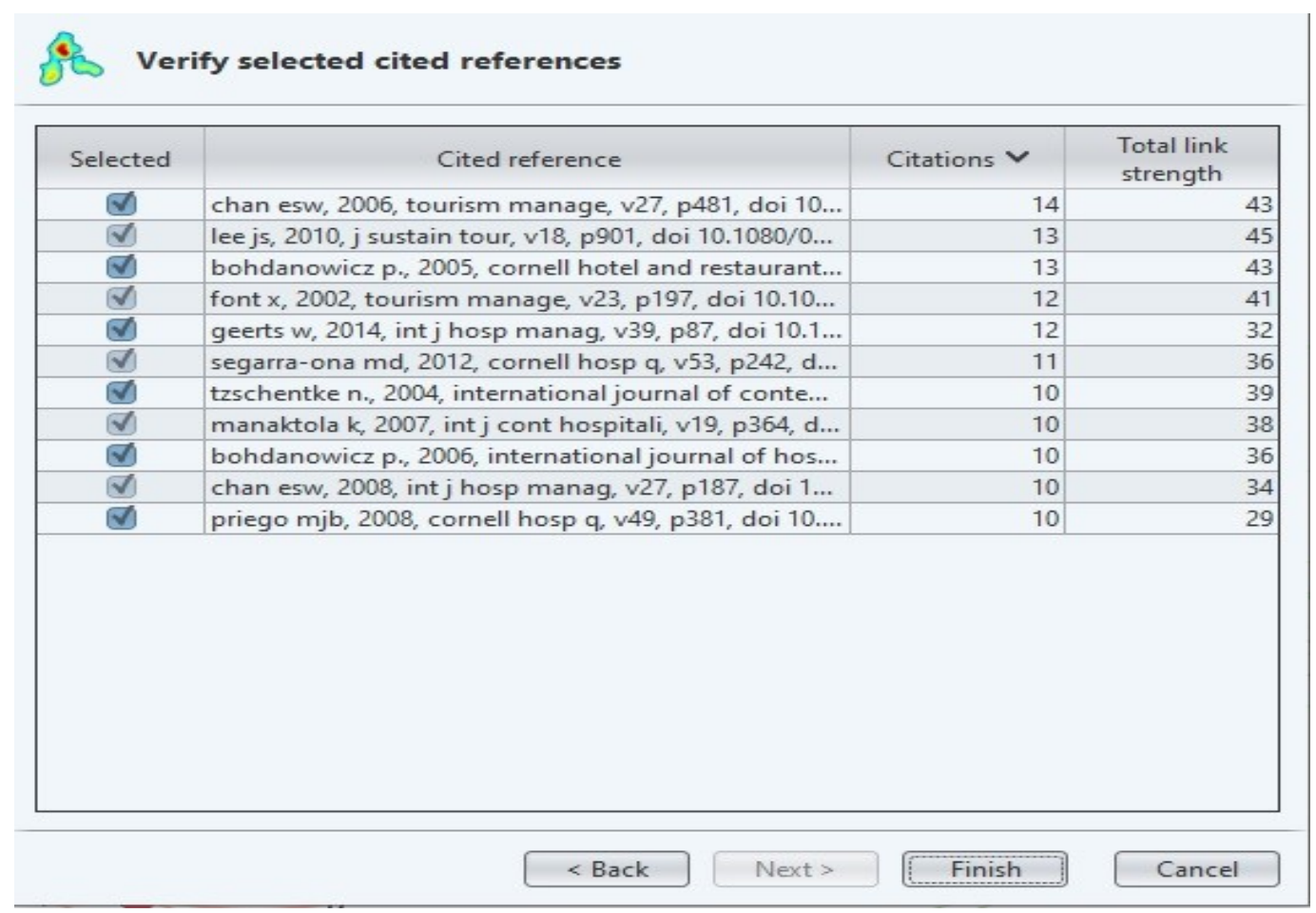

Figure 11. Co-citations

(Source: Created by the authors based on WoS database using VosViewer software)

\subsection{Authors' network}

Fig. 12 illustrates the network diagram for co-authors in the articles used in this study.

It is evident from Fig. 12 that author Verma has joint publications with Peiro-signes, Segarra-Ona, Zhang, and Joglekar, which makes him the most collaborative author. Authors Chan and Rivera have joint publica- tions with three authors, which makes them the second most collaborative authors. Fig. 13 shows that publications of Chan were the most cited, which shows that the author maintains a high-quality research standard. Majority of his articles were published in International Journal of Hospitality Management, which makes this journal the top journal in hospitality management.

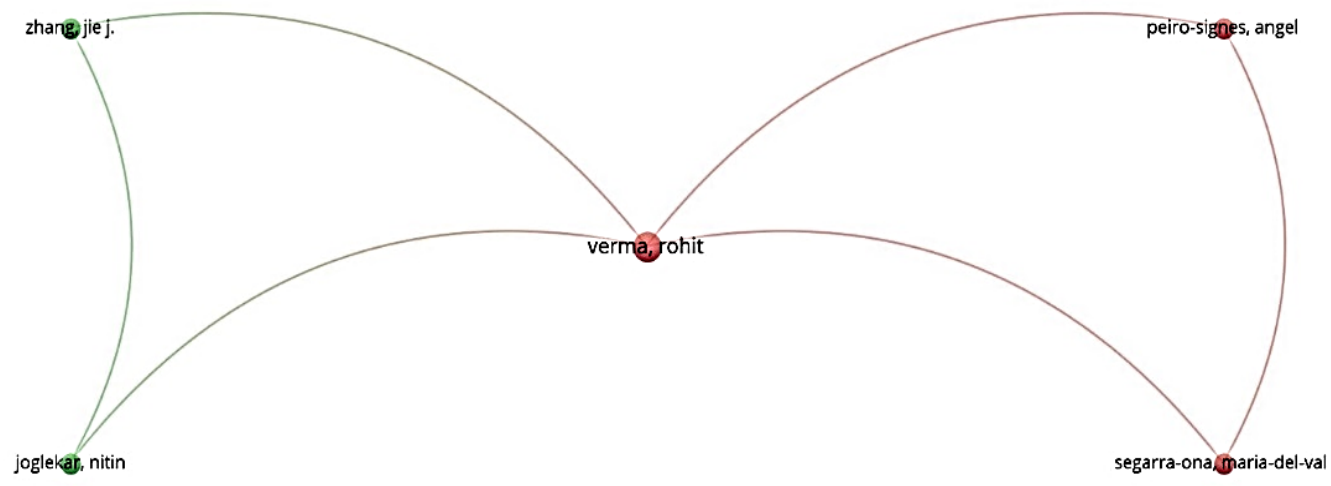

VOSviewer

Figure 12. Co-authorship

(Source: Created by the authors based on WoS database using VosViewer software) 


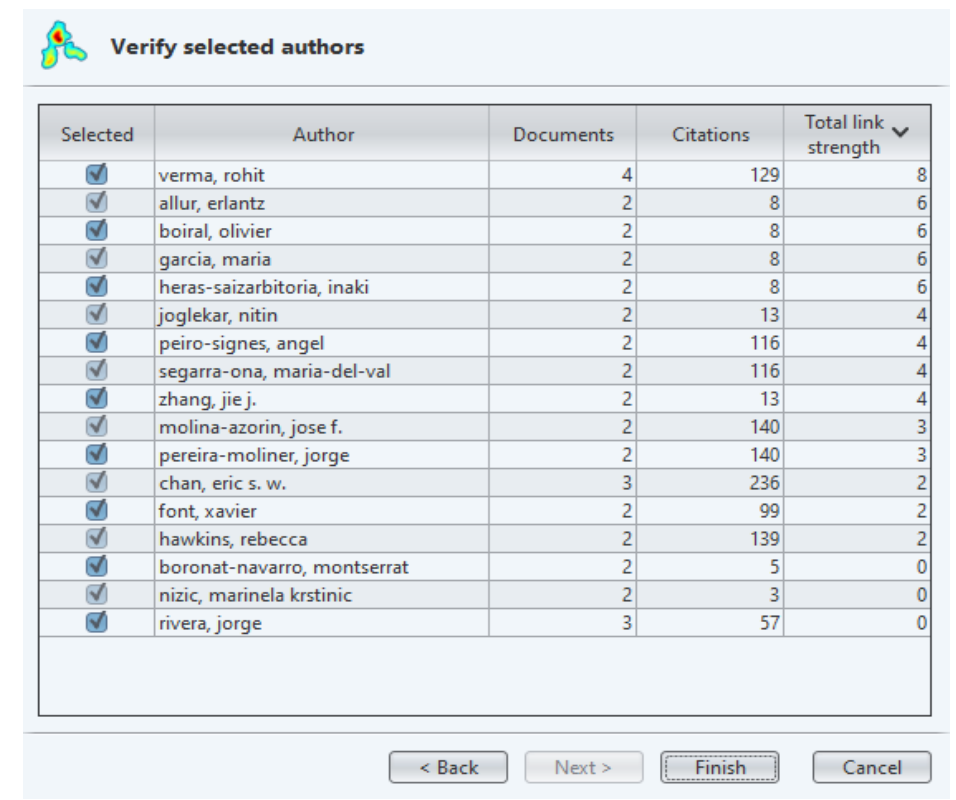

Figure 13. Co-authorship

(Source: Created by the authors based on WoS database using VosViewer software)

\subsection{Keyword co-occurrence}

Fig. 14 illustrates the network diagram for keyword co-occurrence of the articles used in this research, while Fig. 15 shows the table for keyword co-occurrences.

It is evident from Figs 14 and 15 that the keyword "environmental certification" has the strongest link with a frequency value of 19 , which shows that "environmental certification" is the most frequent keyword in the articles used in this research. "Sustainability" and "tourism" were found to be the second strongest keywords with frequencies of 15 and 17 , respectively. Keyword "corporate social-responsibility" was found to be the keyword with weakest link strength.

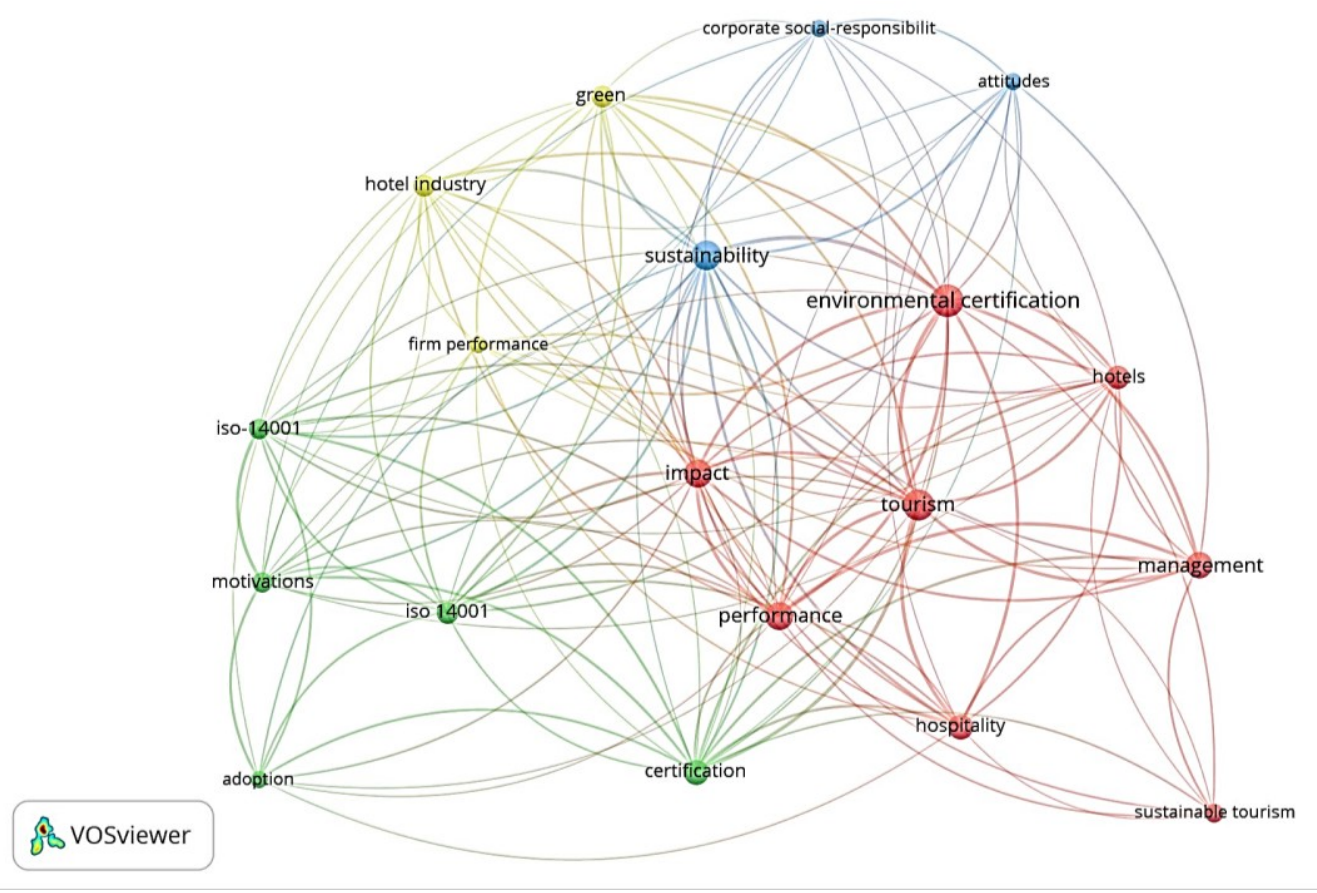

Figure 14. Network diagram for keyword co-occurrence

(Source: Created by the authors based on WoS database using VosViewer software) 


\begin{tabular}{|c|c|c|c|}
\hline Selected & Keyword & Occurrences & $\begin{array}{l}\text { Total link } \\
\text { strength }\end{array}$ \\
\hline$\nabla$ & environmental certification & 19 & 71 \\
\hline$\nabla$ & tourism & 17 & 71 \\
\hline$\nabla$ & sustainability & 15 & 65 \\
\hline $\bar{v}$ & performance & 14 & 57 \\
\hline$\emptyset$ & impact & 14 & 55 \\
\hline$\nabla$ & certification & 11 & 48 \\
\hline$\nabla$ & management & 12 & 44 \\
\hline$\nabla$ & hospitality & 11 & 43 \\
\hline$\varnothing$ & iso 14001 & 9 & 39 \\
\hline$\nabla$ & green & 8 & 36 \\
\hline$\nabla$ & iso- 14001 & 7 & 35 \\
\hline$\nabla$ & hotels & 10 & 33 \\
\hline$\emptyset$ & motivations & 7 & 32 \\
\hline$\nabla$ & hotel industry & 9 & 31 \\
\hline$\nabla$ & firm performance & 5 & 27 \\
\hline$\nabla$ & adoption & 5 & 21 \\
\hline$\nabla$ & attitudes & 5 & 19 \\
\hline$\nabla$ & sustainable tourism & 6 & 14 \\
\hline$\varnothing$ & corporate social-responsibility & 5 & 13 \\
\hline & < Back & Finish & Cancel \\
\hline
\end{tabular}

Figure 15. Keyword co-occurrence table

(Source: Created by the authors based on WoS database using VosViewer software)

\section{5}

\section{Conclusion}

An increase in the number of article publications shows that the topic "Importance of environmental certificates for green hotels" is getting popular among researchers with every passing year. Majority of the journals have articles with a large number of citations, which indicates that they are high-quality journals. The results indicate that Cornell University, Hong Kong Polytechnic University, George Washington University, and Polytechnic University of Valencia are the institutes producing high-quality research work, as $28 \%$ of the researchers cited the articles published by the researchers of these universities.

Results indicate that universities of Spain and USA are the largest contributors, as they have published $52 \%$ of the total articles in the area under this study. Spain and USA are considered to be the world superpowers; their interest in this area of research unveils the importance of topic. The authors Verma, Chan, and Rivera are the core researchers of this area, as they published $20 \%$ of the overall articles discussed in this study, which makes them the gurus of the research area.
It is evident from the research that the keywords "environmental certification," "tourism," and "sustainability" appeared the most among all the keywords used in the articles, which makes them the most significant keywords for this area. Also, $44 \%$ of the articles used in this research were published in the journals "Sustainability," "International Journal of Hospitality Management," "Cornell Hospitality Quarterly," "International Journal of Contemporary Hospitality Management," and "Journal of Sustainable Tourism," which makes them the most popular journals in the area under research.

The study may have some limitations; for example, the researcher might miss to include some useful articles in research. In this research, the researcher used Web of Science database as the main database, while some other databases were also used, which might involve low-quality data set for conducting analysis.

\section{$6 \quad$ References}

[1] Becken, S., McLennan, Ch., 2017. Evidence of the water-energy nexus in tourist accommodation. Journal of Cleaner Production, Vol. 144, pp.415-425. 
[2] Blackman, A., Naranjo, M.A., Robalino, J., 2014. Does Tourism Eco-Certification Pay? Costa Rica's Blue Flag Program. World Development, Vol. 58, pp.41-52.

[3] Chan, E.S.W., 2008. Barriers to EMS in the hotel industry. International Journal of Hospitality management, Vol. 27, No. 2, pp.187-196.

[4] Chan, E.S.W., 2011. Implementing Environmental Management Systems in Small and MediumSized Hotels: Obstacles. Journal of Hospitality \& Tourism Research, Vol. 35, No. 1, pp.3-23.

[5] Chan, E.S.W., Hawkins, R., 2010. Attitude towards EMSs in an international hotel: An exploratory case study. International Journal of Hospitality Management, Vol. 29, No. 4, pp.641651.

[6] Chan, E.S.W., Hawkins, R., 2012. Application of EMSs in a hotel context: A case study. International Journal of Hospitality Management, Vol. 31, No. 2, pp.405-418.

[7] Chan, E.S.W., Wong, S.C.K, 2006. Motivations for ISO 14001 in the hotel industry. Tourism Management, Volume 27, Issue 3.

[8] DeNooy, W., Mrvar, A., Batagelj, V., 2005. Exploratory social network analysis with Pajek. Cambridge University Press.

[9] Geerts, W., 2014. Environmental certification schemes: Hotel managers' views and perceptions. International Journal of Hospitality Management, Vol. 39, pp.87-96.

[10] Hersey, K., 1998. A Close Look at ISO 14000. Professional Safety, 43 (7), pp.26-29.

[11] Kim, S.-H., Lee, K., Fairhurst, A., 2017. The review of "green" research in hospitality, 20002014 Current trends and future research directions. International Journal of Contemporary Hospitality Management, Vol. 29, No. 1, pp.226247.

[12] Manganari E.E., Dimara, E., Theotokis, A., 2016. Greening the lodging industry: Current status, trends and perspectives for green value. Current Issues in Tourism, Vol. 19, No. 3, pp.223-242.

[13] Martinez Garcia de Leaniz, P., Herrero Crespo, A., Gomez Lopez, R., 2018. Customer responses to environmentally certified hotels: the moderating effect of environmental consciousness on the formation of behavioral intentions. Journal of
Sustainable Tourism, Vol. 26, No. 7, pp.11601177.

[14] Peiro-Signes, A., Segarra-Ona, M., Verma, R., 2014. The Impact of Environmental Certification on Hotel Guest Ratings. Cornell Hospitality Quarterly, Vol. 55, No. 1, pp.40-51.

[15] Peiró-Signes, A., Segarra-Oña, M., Verma, R., Mondéjar-Jiménez, J., Vargas-Vargas, M., 2014. The Impact of Environmental Certification on Hotel Guest Ratings. Cornell Hospitality Quarterly.

[16] Pereira-Moliner, J., Font, X., Tarí, J.J., MolinaAzorín, J.F., Lopez-Gamero, M.D., 2015. The Holy Grail: Environmental management, competitive advantage and business performance in the Spanish hotel industry. International Journal of Contemporary Hospitality Management, Vol. 27, No. 5, pp.714-738.

[17] Priego, M.J.B., Najerab, J.J., Font, X., 2011. Environmental management decision-making in certified hotels. Journal of Sustainable Tourism, Vol. 19, No. 3, pp.361-381.

[18] Pritchard, 1969. Statistical Bibliography or Bibliometrics? Journal of Documentation, Vol. 25, No. 4, pp.348-349.

[19] Prud'homme, B., Raymond, L., 2016. Implementation of sustainable development practices in the hospitality industry: A case study of five Canadian hotels. International Journal of Contemporary Hospitality Management, Vol. 28, No. 3, pp.609-639.

[20] Segarra-Ona, Maria-del-Val, Peiro-Signes, A., Verma, R., 2012. Does Environmental Certification Help the Economic Performance of Hotels?: Evidence from the Spanish Hotel Industry. Cornell Hospitality Quarterly, Vol. 53, No. 3, pp.242256.

[21] Susskind, A.M., 2014. Guests' Reactions to InRoom Sustainability Initiatives: An Experimental Look at Product Performance and Guest Satisfaction. Cornell Hospitality Quarterly, Vol. 55, No. 3, pp.228-238.

[22] Tari, J.J., Claver-Cortes, E., Pereira-Moliner, J., 2010. Levels of quality and environmental management in the hotel industry: Their joint influence on firm performance. International Journal of Hospitality Management, Vol. 29, No. 3, pp.500-510. 